\title{
The Paradigm from Traditional Public Administration to New Public Management System in Bangladesh: What Do Reform Initiatives Stand for?
}

\author{
Md. Mizanur Rahman ${ }^{1, *}$, Leslie Sue Liberman ${ }^{2}$, Vincentas Rolandas Giedraitis ${ }^{3}$, Tahmina Akhter ${ }^{4}$ \\ ${ }^{1}$ Department of Social Work, Shahjalal University of Science and Technology, Sylhet-3114, Bangladesh, \\ and EMSRHS Scholar in 2009-2011 \\ ${ }^{2}$ Department of Medical Anthropology, University of Central Florida, Orlando, USA \\ ${ }^{3}$ Faculty of Economics, Vilnius University, Lithuania \\ ${ }^{4}$ Institute of Social Work and Research, Dhaka University, Bangladesh \\ *Corresponding Author: vincasgiedraitis@me.com,
}

Copyright (C) 2013 Horizon Research Publishing All rights reserved.

\begin{abstract}
New Public Management (NPM) system has been the dominant paradigm in public administration theory and practice since the last 30 years determining its affinity with markets and private sector management. Like USA, UK, Korea etc. Bangladesh also adopted vivid reform discourses to transform the paradigm of public administration from Weber's traditional bureaucratic system to the New Public Management (NPM) system. Reform efforts at different times towards underpinning the public sector on the principles of downsizing and entrepreneurship, decentralization, performance management, planning and control cycle could seldom bring successes. Due to many reasons, the NPM system was not introduced in all phases of civil administration except the initiative of privatization of some state-owned enterprises; and thereafter, adopting the policy of public-private partnership. This paper focuses on the failures, and explicit and implicit barriers to the introduction of the NPM system in Bangladesh that was aimed at revitalizing the traditional public administration system. The writer extracted relevant literature and bibliographic databases following exclusion criteria of systematic review method and independently reviewed them to rearticulate the failures behind the paradigm shift in Bangladesh.
\end{abstract}

Keywords New Public Management, Traditional Public Administration, Reform Initiatives, Bangladesh

\section{Introduction}

Bangladesh emerged as an independent state in 1971 after a nine month freedom fight against West Pakistan. The independence brought not only new chapter to the hearts of the millions of Bangladeshis but also placed a heavy burden on the contemporary governments and civil servants to rebuild a nation ravaged by war (Khan 1989). Independence also necessitated a major renovation of the public administrative system that was archaic, anti-people, and inefficient (Ahmed 1980). That is why, from 1972 to the present numerous reform commissions/committees have been constituted in Bangladesh aiming at the paradigm shift from traditional public administration towards new public management (CPD 2001a). Apart from these, a number of studies have been commissioned by international donor agencies. Nonetheless, expected reforms in public administration or introduction of New Public Management are not possible to implement in the old bureaucratic administration in Bangladesh.

\section{Materials and Methods}

The main objective of this essay is to analyze the reform initiatives adopted in public administration with a view to shift the paradigm from traditional public administration to the New Public Management (NPM) and to identify the causes of failures. Relevant articles and bibliographic databases were searched through the OVID (Offshore Vessel Inspection Database) interface. The search strategy was comprised of controlled vocabulary such as keywords focusing on the concepts of reform activities of traditional public administration and failures of implementation of the key elements of the NPM system in Bangladesh. Methodological filters were applied to limit the literature through exclusion criteria of the systematic review.

\section{New Public Management (NPM) System}




\subsection{Introduction of NPM in Public Administration}

New Public Management as a term coined in the late 1980s to denote a new stress on the importance of management and 'production engineering' in public service delivery often linked to doctrines of economic rationalism (Hood 1989; Pollitt 1993). The apparent emergence of a more managerial 'mood' in several countries was to create a need for a new label. The new term was intended to denote public service reform programs that were not confined to the 'new right' in a narrow sense, but also came from labor and social-democratic parties; and in that sense, could be considered as part of what was later labeled a 'third way' agenda. New Public Management is sometimes (understandably) confused with the 'New Public Administration' movement in the USA of the late 1960s and early 1970s (Marini 1971). Although there may have been some common features, the central themes of the two movements were different. The main thrust of the New Public Administration movement was to bring academic public administration into line with a radical egalitarian agenda. By contrast, the emphasis of the New Public Management movement, a decade or so later, was firmly managerial stressing the management to ensure the quality and efficiency of public services that could ultimately focus on public service production functions and operational issues. NPM system contrasted with the focus on public accountability, 'model employer' public service values, 'due process,' and what happens inside public organizations in conventional public administration. How far the small-government economic-rationalist agenda that went together with more stress on public-sector management in the 1980s and 1990s was integral to those managerial ideas is debatable (Barzelay 2000). However, it is hard to separate these elements since the advent of a new generation of public-sector managerialism coincided with concern by numerous OECD (Organisation for Economic Co-operation and Development) governments to reduce the power of public service trade unions, increase regulatory transparency and tackle perceived inefficiencies of public enterprises.

\subsection{Principal Elements of NPM}

New Public Management (NPM) as a topical phrase describes how management techniques from the private sector are now being applied to public services (Lane 2000). This administrative doctrine has been dominating the public administration reform agenda of most OECD countries from the late 1970s (Ridley 1996). NPM shifts the emphasis from traditional public administration to public management (Lane 1994) and also pushes the state toward managerialism (Clarke and Newman 1997). The traditional model of organization and delivery of public services, based on the principles of bureaucratic hierarchy, planning, centralization, direct control and self-sufficiency, is being replaced by a market-based public service management (Walsh 1995; Flynn 1993), or enterprise culture (Mascarenhas, 1993). Its key elements include various forms of decentralizing management within public services e.g., the creation of autonomous agencies and devolution of budgets and financial control, increasing use of markets and competition in the provision of public services (e.g., contracting out and other market-type mechanisms), and increasing emphasis on performance, outputs and customer orientation (Larbi 1999). Conclusively, the key elements of New Public Management (Pollitt 1994) are as follows.

1. A shift in the focus of management systems and efforts from inputs and processes towards outputs and outcomes.

2. A shift towards more measurement and quantification, especially in the form of systems of 'performance indicators' and/or explicit 'standards'.

3. More frequent deployment of market-type mechanisms (MTMs) for the delivery of public services (quasi-market solutions, compulsory competitive tendering)

4. Preference of lean/flat and autonomous organisational forms: decentralisation (i.e. let the managers manage / the right of managing)

5. Favouring contract-like relationships instead of hierarchical relationships

6. Client and quality orientation

7. Blurring the boundaries between public, private and non-profit sectors

8. Value orientation: favoring individualism and efficiency rather than equality and universalism.

\section{Key Reform Initiatives in Traditional Public Administration of Bangladesh}

NPM was largely seen as a developed country, particularly Anglo-Saxon, phenomenon. The 1990s had attempted to apply variants of NPM techniques and practices in some developing and transitional economies. Management decentralization within public services, downsizing, performance contracting, contracting out and user charges were applied in crisis states, but not in a very comprehensive and consistent manner. Downsizing and user fees were most widely introduced, especially in Africa closely associated with structural adjustment programmes. Autonomous agencies within the public sector were created in some countries. Examples included autonomous hospitals in Ghana, Zimbabwe and Sri Lanka, as well as the hiving-off of the customs, excise and internal revenue departments to form executive agencies in Ghana and Uganda. Performance contracting and contracting out became common policy options in a number of crisis states. Few elements were adopted as an instrument to reform state-owned enterprises (SOEs), granting SOE managers more operational freedom by holding them accountable for the performance of the enterprises through a system of rewards and sanctions. Performance contracts were introduced across a number of sectors including utilities, 
transport, telecommunications and agriculture in Ghana, Bolivia, Senegal and India. Contracting out was increasingly adopted in the delivery of public services including urban services such as solid waste management, ancillary health services such as cleaning, laundry and catering in Zimbabwe, and road maintenance in many developing countries (Larbi 1997).

Like other developing countries, reform efforts were launched to shift the paradigm from traditional public administration to NPM in Bangladesh. Decolonization after World War II and adoption of modernization as primary motive necessitated administrative reform in developing countries like Bangladesh (Caiden, 2001). During the Pakistan period, numerous reform programs were undertaken but failed to produce significant results as widespread criticism of anti-democratic practices in the service structure. Bureaucracy unfortunately manipulated all reform measures in its favor (Khan, 1980). After independence, different governments also attempted to incorporate the elements of NPM model in public administration through reform initiatives (Sarker, 2004) that are mentioned below.

- In 1972, Administrative and Services Reorganization Committee, the first attempt, was made to rearrange and unify the civil service structure with a continuous grading system from top to bottom. Because of incapacity and partisan activities of the government, a new administration could not reach success through reform activities. Many credible initiatives were also suggested to ramify the contemporary system but public-sector employees of all categories resisted the move as the recommendations were likely to curb the vested interests of the most powerful group in civil service.

- In 1977, Pay and Services Commission was formed aiming at restructuring a new civil service and pay issues. Though its recommendations were partially implemented, in many cases distortions were observed throughout the policy draft.

- From 1982 to 1988 , some notable measures were adopted such as 'Martial Committee on Examining Organizational Setup of Ministries, Divisions, Directorates and Other Organizations-1982, Committee for Administrative Reform and Reorganization-1982, and Martial Law Committee on Examining Organizational Setup of Public Statutory Corporations-1982' in order to reorganize and rationalize the manpower in public organizations, to reduce the size of government and the layers for decision making, to delegate the administrative and financial powers down the hierarchy, and empower the local authority for rural service delivery. The recommendations of these committees emphasized many issues, some issues were implemented, but the majority portions were never implemented. Consequently, the agenda to rationalize the civil service structure, efficiency, and managerial dynamism, solving intra-service conflict, openness, accountability, and decentralization have long been on the agenda of reforms that still remain elusive in Bangladesh public administration.

- Due to inefficiency in public administration during the 1980s, three donor agencies (e. g. USAID-United States Agency for International Development, UNDP-United Nations Development Programme and Oversees Development Administration, UK) took the initiative and conducted three studies during the period from 1989 to 1993 with a view to reducing layers in decision making, enhancing organization and management capacity, introducing incentives for better performance, improving financial and performance management system, enforcing merit based promotion, developing accountability and transparency.

- In 1993, the Bangladesh government formed another 'Administrative Reorganization Committee' in reducing the size and role of public administration. Like other committees, the recommendations did not fully see the light of implementation.

- In 1996, one of the most crucial initiatives was taken by the World Bank through a study which fixed some targets and called the government for redefining the frontiers of the public sector; expanding the scope of operations for the private sector and nongovernmental Organizations; enhancing the level and nature of accountability and responsiveness; streamlining regulations, laws, and processes; and overhauling the rules and processes and maintaining an efficient, committed, and professional public service. The study was very comprehensive and covered almost all aspects of the NPM model but most of which were not implemented.

- In 1997, the government took another most important step under the 'Public Administration Reform Commission' which also revealed the presence of NPM overtones. Privatization of public enterprises, contracting out of public services, users, reduction of manpower in the public sector, meritocracy in the public service, professionalism, performance standards, citizen's charter, market-based salary structure, devolution of authority to local elected bodies, e-governance, and combating corruption were some of the recommendations that reflected the spirit of NPM to a greater extent.

- In 2008, the interim government made the Regulatory Reform Commission to bring some reforms in general public administration; but the commission has not yet submit the report (Sarker, 2004; World Bank, 1996; GOB, 2000 \& 2008,) 


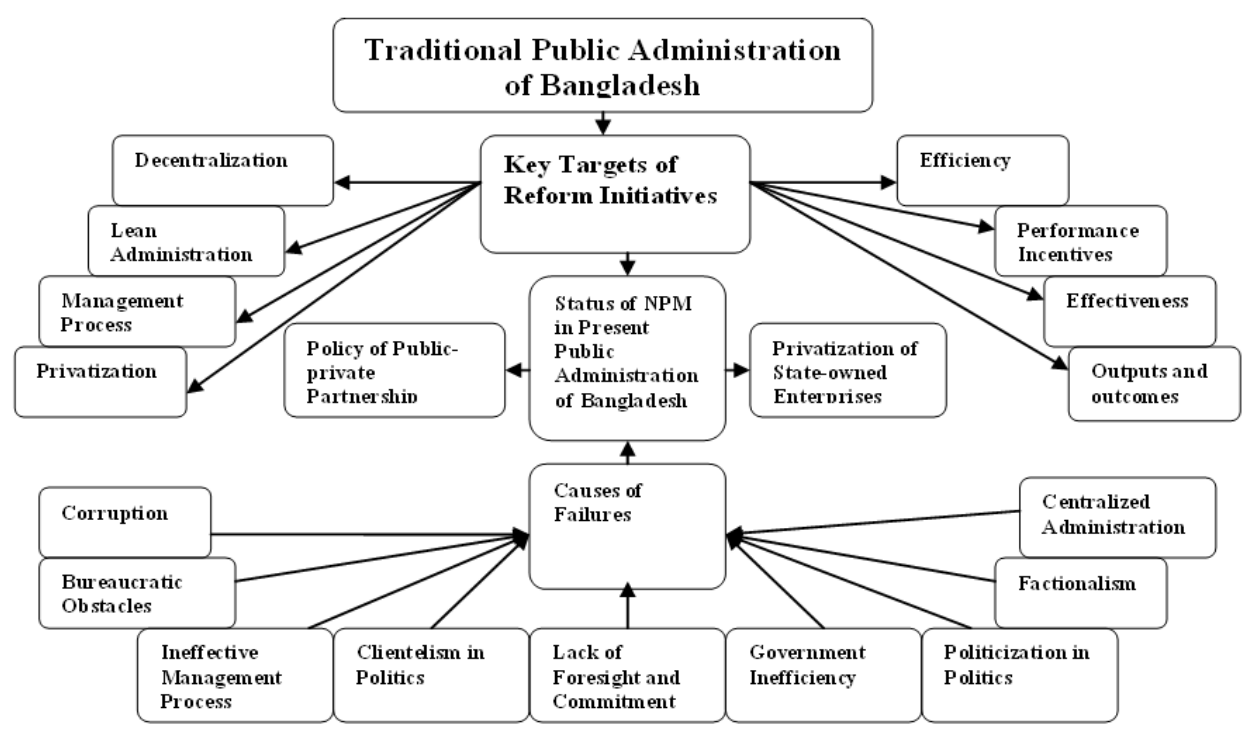

Figure 1. The Flow of Reforms towards NPM and the facts hindering it in Bangladesh

\section{Introduction of NPM System in Bangladesh}

\subsection{Key Successes of the Reform Measures}

Figure 1 shows that although most endeavors have largely failed to make the public administrative responsive, transparent, and efficient, a few successes have emerged from the NPM-style reform tasks. The latest study conducted by ILO (1999) estimates a total 1083 SOEs were privatized during the same period of which 610 were industrial enterprises accounting for $56 \%$ of the total denationalized units (Ahmed, 1999). The SOEs which emerged as a burden of the government because of huge losses annually were either sold or returned to national or international agencies. However, the size of the public sector enterprises have reduced considerably after the paradigm shift in the government's economic policy towards privatization. Since the establishment of the Privatization Board in 1993, and thereafter the Privatization Commission in 2000, 74 state owned enterprises were privatized of which 54 were privatized through outright sale and 20 through offloading of shares. In the national budget (2009-2010), the government has also declared the policy of public-private partnership in health, economy and public administration. Privatization activities, thus, are gaining a momentum in Bangladesh. Decentralization of the public administration in the grass-root levels is seen only in the form of establishment of infrastructures not in the aspects of decision making, planning and resources allocation or outsourcing (Ministry of Finance, Bangladesh)

\subsection{Causes of Failures of Reform Efforts}

As part of NPM, to make the public administration more responsive to the needs of people and more accountable, effective and efficient, the government has so far adopted the above mentioned reforms at different times. However, the recommendations have either not been implemented or implemented in such a way that the real substance was lost. Consequently, administrative reforms did not carry any aspiration and serious attempt in order to shift the paradigm from traditional public administration to NPM. In this case, many factors (see Figure-1) hinder the implementation of NPM-style reforms in Bangladesh. These are:

\subsubsection{Absence of Basic Public Management Processes}

NPM in developed countries is typically used to improve existing institutions where the bureaucracy is meanwhile aware of basic public management processes; but the processes like solid institutional frameworks, rule of law, proper control structures, checks and balances, the civil service system, and accountability systems are either absent or ineffective in Bangladesh. Despite having good intentions, the country has failed to change the precepts of classical organization theory as a way of reinventing government like western administration (Sarker 2004). NPM strategic management, performance management, etc., can be effective only when the basics of administration are in place (Kiggundu, 1989). In this respect, Bangladesh public administration has demonstrated its deficiencies in establishing a rule-based system and enforcing a control structure, resulting in numerous dysfunctional consequences (Huda and Rahman 1989; World Bank 1996).

\subsubsection{Non-cooperation of Bureaucrats}

Cooperation, support and activities of the public bureaucracy play a crucial role when the particular government keeps the NPM-style reform on the table. The reforms have unfortunately faltered in Bangladesh for lack of appreciation and support by the civil servants who are 
responsible for implementing reforms. Most bureaucrats resort to a protectionist attitude toward the insertion of NPM, which usually benefits vested interest groups including themselves. They always consider the reform attempts as downgrading their present status, position, and power and create resistance to distract reform activities. The tendency of most civil servants to preserve the status quo, and, if possible, extend their zone of influence within the public service system, is very much evident in Bangladesh (Khan 1991; Sarker 2004; World Bank 1996).

\subsubsection{Lack of Political Foresight and Commitment}

The foresight and commitment of political leadership work as driving forces to implement the NPM model in public administration. In Bangladesh, few political governments tried to reform the public administration in order to establish the principles and elements of NPM. The reasons include: a lack of knowledge about NPM, the mentality of lengthening the power, the lack of commitment and the fact that political leadership has never been cordial in their attempt to reshuffle the running system and ensure the outcomes, efficiency, performance and accountability in the public administration (Khan 1998). Only during electoral campaigns, the major political parties include the NPM-style reforms as election agenda. After enjoying the power they forget the commitments as they comprehend the immediate political costs of administrative reforms e.g. the administration may play roles against them in the next election. So, suffice it to say that political commitment is circumscribed by clientelist politics in Bangladesh, which is responsible for distracting the movement from traditional public administration to NPM (Sarker 2004).

\subsubsection{Incapability of the Governments}

The government needs capacity and concerted efforts to apply NPM model in the administration through reforms. From independence to till now, almost all governments have miserably failed to demonstrate an extraordinary capacity to realize the recommendations of the reform committees. Besides, many factors can be discerned with the limited capacity of government as well. For example, development agencies constantly break rules and regulations to serve sectional interests (World Bank 1996). Regulatory agencies responsible for maintaining law and order have not performed according to the letter of the law (CPD 2001a). The union of the police and the criminal justice authority, in the hands of the executive government, have simply eroded their autonomy and bred a tendency to the misuse of power for personal and political gain by members of the ruling party (U.S. State Department 2001). The ineffective performance of parliamentary committees as well as lack of follow-up actions by the executive government, the criminalization of politics, the patronage of armed extortionists under political banners, the promoting of social bandits to different political hierarchies, and incessant confrontation between the two major political parties have virtually crippled the prospects of the political and administrative transition and agreement on major national issues. These failures of successive governments in the form of inability to provide basic services such as public goods and services, economic infrastructure, law and order, judiciary and the like are now quite evident as the corresponding market failure, which also hinder NPM-style reforms to the market in Bangladesh (Sobhan 2002 \& 29003; Haque 2001a; Azad 2002; CPD 2001a).

\subsubsection{Clientelism in Politics}

Clientelism, a technical incapacity of Bangladesh, was not only one of the main obstacles in the past, but also creates detriments in the coming days. The clientelist groups as intermediaries are gaining access to resources by organizing pressure which is a serious bottleneck in the reform process in the sense that either the reform programs are not implemented at all, or implemented in such a way that favors clientelist lobbies. No governments have so far taken any initiative in the reform process that is likely to destabilize their own power base. Similarly, it would not be easy to galvanize the civil servants in support of reforms as means to reduce their discretionary authority, privilege, and above all, rent-seeking opportunities. Moreover, the commitment to channel public resources through programs managed by non-governmental agencies (NGOs) and the private sector is bound to cut into strong vested interests (Khan 1989; World Bank 1996).

\subsubsection{Factionalism}

Factionalism among the servants is one of the main causes for not introducing NPM in public administration. From the very beginning of independence, every government has played with the existing factional strife, maintained status quo, and built up their own support base within the public bureaucracy excluding the implementation of reform programs to move towards NPM. Consequently, the deep-seated factionalism has now taken many dimensions (e. g, conflicts between freedom fighters and non-freedom fighters, generalists and specialists, leftists and rightists, military bureaucrats and civilian backgrounds, and factionalism based on district affiliation) (Siddiqui 1996). All the rivalry groups bargain with the political leadership regarding matters affecting their own interests. If the reform program threatens the interests of particular groups, they tend to mount all-out efforts to halt implementation (Sarker 2004). Sometimes the government has also favoured their own supporter groups superseding others. As a result, to ensure individual performance, efficiency, effectiveness, outputs and outcomes in public services have been defied at all times.

\subsubsection{Corruption}

Corruption is deeply rooted in all aspects of public administration in Bangladesh. The whole public administration has been plagued by both political and administrative corruption in a form of bribery, abuse of authority, nepotism, favoritism, patronage, theft, and deceit 
(Khan 1999; Sarker 2001). These phenomena have already emerged as a factor impeding the NPM-style reforms in Bangladesh. Moreover, in the privatization of state-owned enterprises the prospects of private accumulation and patronage distribution are also evident by corruption and over-politicization (Haque 2001a; Akram 1999). A recent evidence shows that due to illicit architectural design and construction abused authority by political favoritism, a eighty-story commercial building was collapsed on 24th April 2013 in Savar, a sub-district in the Greater Dhaka Area, that claimed approximately 2,500 people injured, 2,500 people rescued from the building alive, 1,127 people died and many still missing (The Daily Star 2013). The fact elicits the allegation of wide-spread corruption in public administration that makes a detriment to implement the basic principles of NPM in Bangladesh.

\subsubsection{Politicization of Administration}

Politicization has taken an ugly turn in Bangladesh and its ramifications are detrimental to the basics of administration. Over the last forty years since independence, all governments have tried to entice civil servants as well as to deliver the services for petty party interests. In doing so, they have inducted people under the spoils system, promoted people on party or other petty considerations, politicized the Public Service Commission by appointing people to this constitutional body based on party affiliations and tampered with the selection process to choose party loyalty. The culture of partisanship has infected the bureaucracy to a point where professional advancement is unrelated to performance or integrity. With this pattern of politicization, it is an impossible task to reform the current public administration along the NPM model (Siddque 1996; Sarker 2004).

\section{Conclusion and Recommendations}

NPM in Bangladesh has so far gotten minimal acceptance despite dominating the reform agenda in public administration. Until now, the administration is heavy with unskilled manpower, showing dismal performance. A call for a minimal government is denied. The scale of operations and the role of the government are still in general not on core functions. Bangladesh public administration is lagging behind the fulfillment of the essential conditions of NPM, and achieving very little success (Figure-1). Finally, few steps could be taken to introduce NPM in traditional public administration in Bangladesh:

- The state should play the role to implement the measures recommended by vivid reform committees in order to bring market-oriented changes in the running public administration;

- Performance assessment should strictly be followed for the provision of promotion, up-gradation and time scale of payment of the personnel;

- Wide-spread and rampant corruption should be controlled in all spheres of public administration by value orientation of honesty and efficiency, introduction of incentives and reward of performance and integrity, and identification and appropriate chastisement of the culprits who are corrupt and cooperate others for corruption;

- Politicization of administration should curved by favoring individualism and efficiency rather than disfavoring fanaticism to ideology, and equality and clientelism in politics;

- Efficiency of the personnel could be increased by emphasizing contract-like relationships instead of hierarchical relationships;

- Basic public management process should be introduced and prioritized as the center-piece to run the administration aiming at increasing the capacities of bureaucrats in the public administration.

\section{Acknowledgements}

We are very grateful to experts for their appropriate and constructive suggestions to improve this template.

\section{REFERENCES}

[1] Ahmed, Dr. Mamtaz Uddin. Privatization in Bangladesh, 1999. Available online:http://www.ilo.int/public/english/reg ion/asro/bangkok/paper/privatize/chap2.pdf

[2] Ahmed, E. Bureaucratic Elites and Segmented Economic Growth: Pakistan and Bangladesh, Dhaka: University Press Limited, Bangladesh, 1980.

[3] Akram, T., Ineffective Privatization of Public Enterprises: The Case of Bangladesh, New York: Department of Economics, Columbia University, 1999.

[4] Azad, A.K., Governance: The Terrorist Census, The Daily Star, Internet ed., 13 February, 2002.

[5] Barzelay, M., The New Public Management, University of California Press, Berkeley, CA, 2000.

[6] Caiden, G.E, Administrative Reform, Handbook of Comparative and Development Public Administration, New York: Marcel Dekker, pp. 655-88, 2001.

[7] Center for Policy Dialogue (CPD), Policy Brief on Administrative Reform and Local Government, CPD Task Force Report, Dhaka: CPD, 2001a.

[8] Chowdhury, A., Politics, Society and Financial Sector Reform in Bangladesh, International Journal of Social Economics, 29: 963-88, 2002.

[9] Government of Bangladesh (GoB), Report of the Public Administration Reform Commission, Government Press, Dhaka: Bangladesh, 2000.

[10] Government of Bangladesh (GoB), Report of the Public 
Administration Reform Commission, Government Press, Dhaka: Bangladesh, 2002.

[11] Government of Bangladesh (GoB), Report of the Public Administration Reform Commission, Government Press, Dhaka: Bangladesh, 2008.

[12] Haque, M.S, Recent Transition in Governance in South Asia: Contexts, Dimensions and Implications, International Journal of Public Administration, 24:1405., 2001a.

[13] Hood, C., Public Managemen, New, International Encyclopedia of the Social \& Behavioral Sciences, Elsevier Science Ltd, 2001.

[14] Hood C., Public Administration and Public Policy: Intellectual Challenges for the 1990s, Australian Journal of Public Administration, 48: 346-58, 1989.

[15] Huda, A. T. M., and Rahman, M. A., Delay in Disposal of Cases: A Structural Analysis of the Bangladesh Secretariat", PATC, Savar, Bangladesh, 1989.

[16] Khan, M. M., Administrative Reforms in Bangladesh, Dhaka: University Press Limited, 1998.

[17] Khan, M. M., Resistance to Administrative Reform in Bangladesh 1972-1987, Journal of Public Administration and Development, Vol. 9, pp.: 301-314, 1989.

[18] Khan, M. H. Corruption, Clientelism and Capitalist Development: An Analysis of State Intervention with Reference to Bangladesh, Ph.D. Dissertation, Kings College, University of Cambridge, UK, 1989.

[19] Khan, M. M., Political and Administrative Corruption: Concepts, Comparative Experience and Bangladesh Case, Transparency International, Bangladesh Chapter, Dhaka, Bangladesh, 1999.

[20] Kiggundu, M. N., Managing Organizations in Developing Countries, West Hartford, Conn.: Kumarian Press, 1989.

[21] Khan, M. M., Politics of Administrative Reform: A Case Study of Bangladesh, New Delhi: Ashish Publishing House, 1991.

[22] Khan, M. M., Bureaucratic Self-Preservation: Failure of Major Administrative Reform Efforts in the Civil Service of Pakistan, Dhaka University Press, Dhaka, Bangladesh., 1980.

[23] Lane, Jan-Erik, New Public Management: An Introduction, Routledge Available at:http://www.routledge-ny.com/books/New-Public-Manage ment-isbn9780415231862, 2000

[24] Larbi, George A., The New Public Management Approach and Crisis States, UNRISD Discussion Paper, No. 112, Geveva, Switzerland, 1999.

[25] Marini F., Toward a New Public Administration, Chandler, Scranton, PA, 1971.
[26] Pollitt C, Girre X, Lonsdale J, Mul R, Summa H, Waerness M. Performance or Compliance? Oxford University Press, Oxford, UK, 1999.

[27] Pollitt, C., Modernizing the Management of the Public Services Sector: Between Crusade and Catastrophe?" Paper Presented to the Administrative Development Agency, Helsinki, Finland, 1994.

[28] Sarker, A. E., Administrative Reform in Bangladesh: Three Decades of Failures, International Public Management Journal, Vol. 7, No. 3, ISSN: 1096-7494, 2004.

[29] Sarker, A. E., New Public Management in Developing Countries: An Analysis of Success and Failure with particular reference to Singapore and Bangladesh, International Journal of Public Sector Management, Vol. 19, Issue-2, pp.: $180-203,2006$.

[30] Sarker, A. E. New Public Management in Bangladesh: Chasing a Mirage?, Indian Journal of Public Administration, 47:154-69. , 2001.

[31] Siddiqui, K., Towards Good Governance in Bangladesh: Fifty Unpleasant Essays, Dhaka: University Press Limited, 1996.

[32] Sobhan, R., The Crisis of External Dependence: The Political Economy of Foreign Aid in Bangladesh, Dhaka: University Press Limited, 1981.

[33] Sobhan, R., The Political Economy of the State and Market in Bangladesh, Center for Policy Dialogue, Dhaka, Bangladesh, 2002.

[34] The Daily Star - Bangladesh, The Daily Star, Dhaka, Bangladesh. Available at www.thedailystar.net, 2013.

[35] Walsh, K., Public Services and Market Mechanisms: Competition, Contracting and the New Public Management, London: Macmillan, UK, 1995.

[36] World Bank,Bangladesh: Government That Works Reforming the Public Sector, Dhaka: University Press Limited, Bangladesh, 1996.

[37] World Bank, Bangladesh: Privatization and Adjustment", Dhaka, Bangladesh Available at http://www.pc.gov.bd/, 1994. Website Accession

[38] Transparency International - Bangladesh, available at http://www.ti-bangladesh.org

[39] United Nations Development Programme (UNDP), available at http://www.un-bd.org/undp/

[40] World Bank (WB-Bangladesh), available at http://www.worl dbank.org/bd

[41] Ministry of Finance, Bangladesh, available at httpwww.mof. gov.bdenbudget09_10 